Canadian University Music Review

Canadian University Music Review

Revue de musique des universités canadiennes

\title{
John Rink and Jim Samson, eds. Chopin Studies 2. Cambridge: Cambridge University Press, 1994. x, 253 pp. ISBN 0-521-41647-7 (hardcover)
}

\section{Glenn Colton}

Volume 17, numéro 1, 1996

URI : https://id.erudit.org/iderudit/1014703ar

DOI : https://doi.org/10.7202/1014703ar

Aller au sommaire du numéro

Éditeur(s)

Canadian University Music Society / Société de musique des universités canadiennes

ISSN

0710-0353 (imprimé)

2291-2436 (numérique)

Découvrir la revue

Citer ce compte rendu

Colton, G. (1996). Compte rendu de [John Rink and Jim Samson, eds. Chopin

Studies 2. Cambridge: Cambridge University Press, 1994. x, 253 pp. ISBN

0-521-41647-7 (hardcover)]. Canadian University Music Review / Revue de

musique des universités canadiennes, 17(1), 134-137.

https://doi.org/10.7202/1014703ar

All Rights Reserved (C Canadian University Music Society / Société de musique des universités canadiennes, 1996
Ce document est protégé par la loi sur le droit d'auteur. L'utilisation des services d'Érudit (y compris la reproduction) est assujettie à sa politique d'utilisation que vous pouvez consulter en ligne.

https://apropos.erudit.org/fr/usagers/politique-dutilisation/ 
material on England is too limited for a separate chapter) and traces the rise of the piano in public estimation. The format involves endnotes rather than footnotes, which renders the body of the book easier to read. The bibliography is selective, but excellent.

I found this book to be very thorough and detailed, yet so well presented as to be enjoyable by readers from many areas. While it is certainly a wonderful resource for the technician, it is also of interest for performers and historians interested in the early pianoforte. Pollens's description of the sound quality of the instruments wherever possible, and the music written specifically for these early instruments is especially useful, increasing the scope of the book. His research methods are meticulous and consistent, and well-documented by tables, diagrams, original manuscripts, and photographs, so that the reliability of his statements cannot be questioned. I would recommend this book to all concerned with the early pianoforte.

Lynda Smyth

John Rink and Jim Samson, eds. Chopin Studies 2. Cambridge: Cambridge University Press, 1994. x, 253 pp. ISBN 0-521-41647-7 (hardcover).

Chopin Studies 2, the companion to Cambridge University's first, analyticallycentred volume of Chopin studies (1988), encompasses a wide spectrum of subject matter and methodology relating to three main fields of inquiry: reception history, aesthetics and criticism, and performance studies. The present volume comprises a series of twelve essays-by Jim Samson, Andreas Ballstaedt, Anne Swartz, Jeffrey Kallberg, Karol Berger, Anthony Newcomb, Jean-Jacques Eigeldinger, Edward T. Cone, Carl Schachter, L. Henry Shaffer, David Rowland, and John Rink-with an appendix by Jeremy Barlow.

\section{Reception History}

The topic of Chopin reception is first approached by Jim Samson, with an informative introductory section on nineteenth-century reception history. While Samson's essay offers some insightful theories on the implications of reception studies for music history and analysis, the general overview of Chopin reception is perhaps too general. Instead of offering a brief synopsis of Chopin reception by French critics, German publishers, Russian composers, and English amateurs, as Samson has done, a more effective strategy may have been to focus on a single receptive field, critics for example. Such a study could compare critical reception in France, Germany, Russia, and England, and theorize as to the reasons behind any discrepancies.

"Chopin as 'salon composer' in nineteenth-century German criticism," by Andreas Ballstaedt, documents recurrent references to the salon milieu in German criticism of Chopin's music, but provides little evidence to support the author's assertion that such references held negative connotations for the composer. Ballstaedt's text selection, which excludes journal articles and reviews other than extended essays, is questionable. Anne Swartz explores 
Chopin reception history in nineteenth-century Russia by revealing how Chopin's music satisfied the philosophical needs of both the "Westernisers," proponents of the Western European romantic tradition, and the "Slavophiles," a group of intellectuals ideologically grounded in the Orthodox Church (p. 35). Although this type of categorization oversimplifies the complex critical climate of mid-century Russia, Swartz's essay convincingly demonstrates how the Slavophiles's perception of Chopin as a "modern" composer was conditioned by aspects of musical style and political ideology.

One of the more provocative titles in the book is "Small fairy voices: sex, history, and meaning in Chopin," by Jeffrey Kallberg. In this essay, Kallberg examines the perceived sexual connotations underlying otherworldly metaphors invoked in nineteenth-century descriptions of Chopin. The author provides a conceptual framework for his hypothesis by documenting the sexually ambiguous meanings of otherworldly metaphors in contemporary literature and philosophy, most notably in France. Of particular interest is Kallberg's discussion of George Sand's Gabriel (1839), the fictional story of "a young member of the nobility whose 'true' female sex has been disguised from her since birth" (p. 59). Aside from its autobiographical overtones, Gabriel offers a probing critique of nineteenth-century views on gender and sexuality and, "with its abundance of imagery relating to angels and sexual ambiguity, it clarifies the routes by which metaphorical stylisations of Chopin as an angel could take on sexual connotations" (p. 59).

\section{Aesthetics and Criticism}

Chapters Five and Six-by Karol Berger and Anthony Newcomb, respectively-address the topic of musical narrativity through contrasting historical and analytical perspectives. Berger posits the existence of a relationship between the temporal structure of Chopin's music and the temporal structure underlying the historical narratives of the Polish émigré circle in the Paris of the 1830s. To reinforce the composer's affiliation with this circle, the author stresses the close personal and philosophical connection between Chopin and one of its most influential members, the poet Adam Mickiewicz. ${ }^{1}$ While the author's discussion of the multi-faceted ideology of Polish romanticism is interesting and informative, the connection between historical narrativity and musical narrativity in the Ballade in $\mathrm{G}$ minor, op. 23, is less convincing. The author's analytical discussion of the work is confined to a single opening paragraph. Thereafter, only passing reference is made to the Ballade as one of "many of Chopin's major one-movement narrative works" (p. 81), each of which may be explored within the context of Polish romantic ideology.

Newcomb's article, "The Polonaise-Fantasy and issues of musical narrative," offers a more comprehensive discussion of musical narrativity as it applies to instrumental music generally and Chopin's music specifically. In addressing the broader issue, the author identifies two elements necessary for

1 To further this connection, I would add that Chopin selected text by Mickiewicz for inclusion in the nineteen Chants polonais, op. 74, arguably some of his most overtly nationalistic compositions. 
narrative interpretation: intrinsic musical characteristics which suggest narrativity, and external criteria by which the listener identifies narrative aspects in the music (p. 85). In the Polonaise-Fantasy, op. 61, Newcomb argues, internal narrativity derives from certain "musical detours" in the piece (i.e., formal segmentation, thematic interrelations, conflicting generic signals) (pp. 87-88). The second element, contributed by the listener, complements the first to produce the narrative itself which, as the author acknowledges, "may vary widely according to the listener, the listening occasion and the cultural context" (p. 88).

Chopin's compositional aesthetic is the focal point of a lengthy essay by Jean-Jacques Eigeldinger, in which the author documents the dominant influence of the musical past (particularly the idiom of J.S. Bach) on the composer's aesthetic outlook. Although Eigeldinger deals extensively with instances of quotation and influence, references to the recent theories of influence proposed by authors such as Joseph Straus and Kevin Korsyn are conspicuously absent. ${ }^{2}$ One of the highlights of the book is Edward T. Cone's essay "Ambiguity and reinterpretation in Chopin." Well-written and thoroughly researched, it offers an enlightening perspective on Chopin's harmonic, metrical, and formal ambiguities through an approach which Cone terms "intentional analysis" (p. 141). This approach explores the multiple interpretations suggested by Chopin's ambiguities in an effort to "ascertain, as far as possible, how the composer wished us to hear his music" (p. 141).

\section{Performance Studies}

The final four chapters discuss interpretative aspects of specific works as well as the broader issues of intertextuality, tempo rubato, and authenticity. Carl Schachter's essay addresses issues of form, tonal structure, and expression arising from two autograph sources of the Prelude in E minor, op. 28, no. 4, and posits a performance strategy based on these considerations. Perhaps the most remarkable aspect of Schachter's study is his intertextual reading of the prelude as it relates to the Mazurka, op. 41, no. 1. Through a combination of analytical and documentary evidence, the author builds a convincing case to support his theory that the two works represent "two flowers growing from a single branch" (p. 168). An interesting mixture of analysis, source study and interpretation, Schachter's essay serves as a microcosm of the eclectic approach which characterizes the book as a whole.

A radically different strategy is employed by $L$. Henry Shaffer to investigate the relationship between structure and expression in the Prelude in F-sharp minor, op. 28 , no. 8. By quantifying expressive aspects of one particular recording of the piece via a computerized numerical sequence, Shaffer proposes a method of assessing a performer's musical proficiency with respect to the work's structural and historical context. While this approach offers an

2Most notable among these studies are Straus's Remaking the Past: Musical Modernism and the Influence of the Tonal Tradition (Cambridge, Mass.: Harvard University Press, 1990), and Korsyn's "Towards a New Poetics of Musical Influence," Music Analysis 10, nos. 1/2 (1991): 2-72. 
alternative to performance evaluation, the merit of dissecting a single, anonymous recording is questionable. A more informative approach may have been to expand the comparative sampling of pianists cited on page 197, assessing the relative merits and deficiencies of each. ${ }^{1}$ David Rowland contextualizes tempo rubato markings in Chopin by exploring the history of rhythmic flexibility in the eighteenth and nineteenth centuries and demonstrating how the nature of Chopin's rubato varied according to genre and texture. Concise and well-written, Rowland's essay offers some useful guidelines for a historically informed performance.

The final chapter, by John Rink, is based on the premise that authentic peformance may be defined simply as "convincing interpretation" (p. 215), a view the author attempts to substantiate with the contentious assertion that the historical performance movement represents an impediment to the performer's artistic freedom (pp. 214-15). Ironically, the greatest strength of this essay is its analytical and historical data, most notably the author's discussion of rhythmic shape in the D major Prelude, op. 28, no. 5. The construction of a hypothetical polemic between "historical" and "intuitive" performance, however, dilutes the persuasiveness of Rink's argument considerably. The book concludes with Jeremy Barlow's presentation of Fanny Erskine's Paris diary (1847-48), which documents several encounters with Chopin.

Chopin Studies 2 gathers together many diverse strands of Chopin research with variable success. Despite its flaws, this volume succeeds in expanding the scope of its predecessor and, indeed, many of the essays extend far beyond the realm of Chopin studies to address broader issues of relevance for the performance, analysis and history of nineteenth-century music. It is precisely this eclecticism which makes the book a valuable reference tool for music scholars of wide ranging interests.

Glenn D. Colton

Percy Young. Elgar, Newman and The Dream of Gerontius: In The Tradition of English Catholicism. Aldershot, Hampshire: Scolar Press, 1995. 162 pp. ISBN 0-85967-877-6 (hardcover).

Stewart R. Craggs. Edward Elgar: A Source Book. Aldershot, Hampshire: Scolar Press, 1995. 188 pp. ISBN 0-85967-920-9 (hardcover).

Cardinal Newman was the nineteenth century's most famous convert to Roman Catholicism. As an Anglican cleric, and one of Oxford's leading intellectuals, he had preached sermons describing Rome as "the whore of Babylon." When the conversion came it was spectacular. Rome offered him the diocese of Westminster, its highest position in England, and Newman thereafter exercised an unparalleled influence in Catholic affairs.

1 Shaffer briefly compares performances by Artur Rubinstein, Nikita Magaloff, Martha Argerich, Vladimir Ashkenazy, Maurizio Pollini, and Livia Rev. 